\title{
Identities, Language, and Wayang Gung of South Kalimantan
}

\author{
Rezqan Noor Farid ${ }^{1}$, Muhammad Yunus ${ }^{2}$ \\ ${ }^{1}$ Universitas Muhammadiyah Banjarmasin, Banjarmasin \\ 2 Universitas Muhammadiyah Banjarmasin, Banjarmasin \\ ${ }^{1}$ rezqanfarid@umbjm.ac.id, ${ }^{2}$ hammadyunus@umbjm.ac.id
}

\begin{abstract}
Art products are media to show the identities of their makers and the identities of society members enjoying them. Cultural and communal traits of society where the arts are created and appreciated are reflected through the arts. Wayang Gung is a classic art from South Kalimantan rarely performed nowadays. Wayang Gung depicts the cultural values of the Banjarese people in the past. As one of the valuable oral literature of Banjarese, the linguistic element of Wayang Gung is worth investigating to reveal the identities and cultural traces of Banjarese people. In this study, scripts of Wayang Gung are collected through documentation techniques and analyzed using the Ethnolinguistics approach. Ethnolinguistics is chosen for analyzing tools as it focuses on investigating the language used in society with that society's culture. Furthermore, ethnolinguistics seeks to reveal the identities of the language users. The results of this study show that Banjarese people consider.

Keyword: Wayang Gung, Banjarese, Ethnolinguistics
\end{abstract}

\section{INTRODUCTION}

In South Kalimantan, the mother tongue of Banjarese is the Banjarese language. It language has been developed since the time of Nagara Dipa and Daha Kingdoms. Vocabularies of the Banjarese language share similarities with Dayak, Malay, and Javanese languages. Banjarese people are closely related to the three ethnics since a long time ago. The first kingdom in South Kalimantan, Nagara Dipa was found by Ampu Jatmika with his two sons, Lambung Mangkurat and Mpu Mandastana who came from Keling of Java. Banjarese culture is also influenced by Dayakese culture. For example, the traditional ritual of Baayun Maulid in Banjarese culture is rooted in the ritual of giving blessings to a kid in Dayak Kaharingan culture. Interrelation between Banjarese and Malay is also strong as the word 'Banjar' is derived from the Malay language. 
Despite being influenced by other ethnicities, Banjarese people still have their own identities. Identity refers to certain attributes or characters that belong to an individual or community. Identity has two sides; it is either showing similarities or differences among people. Members of a community commonly share similar beliefs, values, and customs that differ them from other communities. These beliefs, values, and customs become their identities. Identities of a community are observable through the attitudes and language of its members. In relation to identities, language serves at least two functions. First, it is the media channeling community wisdom. Second, language is the media of identifying self for every individual. By using language, someone clarifies whether or not their attitude, way of speaking, belief, and so on are in accordance with their communal identities.

In this study, the researchers intend to reveal Banjarese people's identities by investigating the scripts of Wayang Gung. Wayang has been part of South Kalimantan since the $14^{\text {th }}$ century. It was first introduced to Nagara Dipa Kindom in Amuntai. The oldest form of wayang is Wayang Purwa. In South Kalimantan, Wayang Purwa was developed into other forms of wayang, including Wayang Gadongan, Babaksan, Manopeng, and Wayang Gung. Wayang Gung is human puppet show from South Kalimantan. It is one of the theatrical plays commonly played by a group of people who act and dance on stage and another group of people who plays musical instruments for the play. Usually, 10 to 12 people are playing Wayang Gung. The players usually only play one role for the rest of their career in Wayang Gung so that each player can be absorbed in their role. It is the reason why the scripts of Wayang Gung are hard to find. Some groups of Wayang Gung may perform without scripts because they know the storyline and their roles. It is enough for them to give an unscripted impromptu performance.

To accompany the players' acting and dancing, 10-11 people playing musical instruments for Wayang Gung. The main musical instruments in Wayang Gung are gamelan and kenong. Wayang Gung performance is led by three puppet masters named Dalang Utusan, Dalang Pangambar, and Dalang Sejati. Each puppet master has his role. Dalang Sejati usually opens the play by praying to God for its success and 
narrating the play. The opening of Wayang Gung is called mamucukani. All performers are introduced at this mamucukani phase.

The act performed in Wayang Gung is Ramayana with the local touch of South Kalimantan. As stated on the Kemdikbud website, Wayang Gung is similar in several aspects to Wayang Orang from Java. It is because the roots of Wayang Gung and Wayang Orang are the same. However, the two audiences will notice that Wayang Gung is presented in different costumes, dances, and languages than Wayang Orang. It is because the locality of South Kalimantan is strong in Wayang Gung.

(Natalika, 2014), as cited in https://budaya-indonesia.org/Wayang-Gung, mentions that there are five functions of Wayang Gung. The first function is the entertainment function. Wayang Gung is a traditional theatrical play created to entertain people during certain events. The second function is the didactic function. Wayang Gung is didactic as it is a medium to convey good messages to its audiences. The third function of Wayang Gung is the philosophical function. Wayang Gung acts tell its audiences about material and spiritual life, values, and other philosophical teachings. The fourth function of Wayang Gung is to fulfill nazar. Nazar is the promised one made to perform when his/her willingness are granted. Nazar is a common practice for Banjarese people, usually Muslims, to show gratitude over big blessings they have received. The last function of Wayang Gung is as part of a magical ritual. Wayang Gung is believed to have a certain magical effect that can cast away or avoid sickness and disaster from happening.

Wayang Gung was performed all night long as part of Banjarese people's big celebrations on its glorious days. Nowadays, it is no longer common to see Wayang Gung performed the wedding or harvest celebration. To keep the audiences seated, Wayang Gung has also been performed in a shorter period (around 2 to 4 hours) in the past few years. The ease for modern people of Banjar to access various entertainment kinds makes Wayang Gung lost its fame.

Wayang Gung is chosen as the object of study because of two reasons. First, the researchers wish to take part in introducing Wayang Gung to the public through academic work. Wayang Gung is no longer popular even in South Kalimantan, where 
this art is originated. Therefore, the researchers wish by introducing Wayang Gung through this work; more people will realize the worth of this traditional inheritance. Second, Wayang Gung is a classic art highly influenced by values hold by Banjarese people. Thus, investigating the scripts of Wayang Gung enables the researchers to reveal the identities of Banjarese people.

\section{METHODS}

The main objective of this study is to describe language identities reflected in script excerpts of Wayang Gung. As this study is not intended to generalize any fact but rather explain phenomena in certain settings, this study is carried out as a descriptive qualitative study. According to (Mukhtar, 2013), a descriptive qualitative study investigates certain phenomena to describe them then as they are. The technique of data collecting in this study is documentation. (Sugiyono, 2008) mentions that one of the most crucial techniques to collect qualitative research data is documentation. Therefore, the documentation technique applied in this study is suitable for its descriptive qualitative research design.

The data of this study are gathered from two books containing Wayang Gung scripts. The lexicons used in the scripts are sorted; then, the lexicons are analyzed based on their meanings using an ethnolinguistics approach. Ethnolinguistics is a multidisciplinary study that combines ethnography and linguistics. According to (Endraswara, 2015), ethnography deals with the picture of a country, ethnicity, and race, which include customs, habits, laws, arts, religions, and language. Meanwhile, (Foley, 2001) states that ethnolinguistics sees language through anthropological concept views, which is culture; it attempts to reveal the meaning behind "the use, misuse or non-use of language" through its different styles and forms. In other words, ethnolinguistics is the study of language that deals with how the community's language is regarded as part of its culture. Ethnolinguistics also studies how language is treated as a useful tool to understand and investigate culture.

In ethnolinguistics, meanings of a word, phrases, and other forms are crucial objects of investigation. A set of sound symbols we produce from our speech organs 
is meaningless unless we, as other society members, give them meanings based on mutual convention. According to (Chaer, 1994) and (Wakit, 2014), meanings can be divided into lexical and cultural. Lexical meaning refers to the literal meaning of a word. It connects the word and its reference in the real world. From lexical meanings of words in a language, we can infer knowledge, beliefs, and ways of life of the community speaking the language. Cultural meaning refers to the meaning behind symbols used as guidance for the daily lives of community members. These symbols portray certain objects or events. Members of society recognize the meanings behind the symbols as they have shared knowledge about those symbols. Cultural meanings are contextual; it means that the same symbols may have different meanings in different places. In this study, the lexicons gathered are analyzed lexically and culturally.

\section{RESULTS AND DISCUSSION}

After analyzing the scripts of Wayang Gung, the researchers conclude that Banjarese people own several identities related to spirituality, persistence, and togetherness.

Subsequent paragraph text.

\subsection{Religiousness}

The spirituality of the Banjarese people is part of their identities. Islamic teachings, either pure ones or assimilated ones, affect the way people live in this society. In the scripts of Wayang Gung, three lexicons depict Islamic teachings. The first word is berelaan. The literal meaning of berelaan is the completion of a deal. It word is usually uttered when someone has a business or transactional needs with other people. Berelaan is uttered by the end of business or transactional activities to indicate neither hard feelings nor unfinished issues for both parties.

Culturally, berelaan has a deeper meaning. It indicates the submissive trait of the Banjarese people. Berelaan means whatever happens during the deals with others is for Allah and because of His will. By uttering this, Banjarese people also expect their partners to let go and forgive all mistakes and shortcomings during the deals. 
Disappointing others in any way will make them feel unease. Islam teaches its followers to seek forgiveness not only to Allah but also to those being hurt by them. Therefore, berelaan is part of Banjarese identities. It shows how afraid Banjarese is to make mistakes to others and obey the command of Allah.

Other lexicons found in the script of Wayang Gung that portrays the religious identity of Banjarese are jual and tukar. The two lexicons are commonly uttered in trading activities. The literal meaning of jual is selling. The traders utter this word to notice their buyers that the transactions have been made. Meanwhile, the literal meaning of tukar is buying. The buyers utter this word to indicate they have accepted the transactions. Jual and tukar usually come in a package. These lexicons are common for Banjarese but may sound odd for people from other cultures who do not know why the lexicons are uttered.

Culturally, jual and tukar are highly related to Islamic teaching. In Islam, akad or trade deal should be made between the traders and the buyers to make sure both parties agree to their transactions. The root of this deal is honesty. Islam teaches its followers to do practice clean and honest business. Jual and tukar indicate both parties in the trade agreement on the price and quality of the traded goods. According to Islamic teaching, any trade without akad will not be valid and will not get any blessing from Allah. Therefore, jual and tukar are important in trading activities for Banjarese. It fact shows how Banjarese lives Islamic teaching as part of their identities.

\subsection{Persistence}

Persistence is also part of Banjarese identities. The persistent nature of Banjarese is reflected in the word cangkal and the phrase waja sampai kaputing found in the script of Wayang Gung. Cangkal means work diligently and persistently. Cangkal means giving the best for our job no matter how hard it is. Cangkal is usually closely related to hard-working people who try their best to provide for the family or to give maximum results for whatever they do. 
Culturally, cangkal means that life is not always easy, so we have to be strong and persistent. Cangkal shows how Banjarese people are used to working hard in their life. Cangkal portrays sacrifice, willingness to improve, and courage to think and act out of the box. Banjarese people are famous for madam - moving to another place for a better life. It is why Banjarese people can be found in many places all over Indonesia, Malaysia, Brunei, and Saudi Arabia. The cangkal trait in them makes them willing to work extra hard, even being separated from family, to pursue a better life.

Beside cangkal, haram manyarah waja sampai kaputing also shows persistence of Banjarese people. The literal meaning of haram manyarah is it is sinful to give up. Meanwhile, the literal meaning of waja sampai kaputing is steels to the end. Steels are not easily welded metal. Steels to the end mean being strong and persistent from the start to the end to achieve the goal. Haram manyarah waja sampai kaputing is motto of South Kalimantan province. Pangeran Antasari shouted this motto, one big figure in the history of Banjar, to lit the spirit of Banjarese fighters when Banjar was still colonialized by Dutch soldiers. It motto means Banjarese people will not give up easily.

Culturally speaking, haram manyarah waja sampai kaputing teaches the value of loyalty along with persistence. As human beings, Banjarese people are expected to be loyal to their roots. Banjarese people need to stay true to who they are. They have to be strong like steels and be reckless pursuing what they believe is right even if things do not run as expected. In other words, haram manyarah waja sampai kaputing portray the firm stance of Banjarese people. It also becomes part of their communal identities.

\subsection{Togetherness}

Banjarese people appreciate togetherness and take it as part of their identities. Some lexicons found in the scripts of Wayang Gung confirm this. The lexicons are bubuhan, dingsanak, and kula.

The literal meaning of bubuhan is people. Bubuhan is used to identify a group to differentiate this group from another. Its lexicon is found everywhere in South 
Kalimantan. We can find the word bubuhan in stores, food stalls, and daily conversation. Bubuhan depicts togetherness among people. Like two sides of the coins, bubuhan also depicts separation and a 'not-belong-there' sense of people outside the group.

Culturally, bubuhan refers to a bond within a social group in Banjarese society. Each bubuhan has its own identity and background. Bubuhan is also related to social segmentation in which consists of a leader and followers. The existence of leadership patterns in bubuhan is usually based on age and experience. Bubuhan Banjar are phrases commonly used to refer to Banjarese people. It is like the tag that Banjarese people are one. It depicts the pride of the Banjarese people in their culture and roots.

The second lexicon portraying togetherness found in the scripts of Wayang Gung is dingsanak. Dingsanak means sister or brother. In Banjarese society, dingsanak is used to refer to blood-related siblings and people that we consider close. Banjarese people use dingsanak to convey their closeness to their friends and relatives. The use of dingsanak shows intimacy; people do not need to be blood-related to feel like family.

The cultural meaning of dingsanak is highly related to the fact that Banjarese people love to live communally. They tend to choose to be together and be close to each other even it means they have to share what they have. Dingsanak depicts deep trust in others; you can only call someone dingsanak in Banjarese culture when you have an interpersonal bond built upon the experiences you share with that person.

The last lexicon found in the scripts of Wayang Gung that portrays togetherness is kula. The literal meaning of kula is family. The word family in Banjarese culture does not refer to parents and kids only but also includes big family members like grandparents, uncles, aunties, cousins, etc. Banjarese people love to seek their kula. That is why asking your origin and family background is a common practice in Banjar. This practice is intended to reveal whether or not the people are related.

From on cultural point of view, kula means the closeness worth maintaining. Banjarese people tend to treat others as if they are treating their own family. Banjarese people are generally very welcome to others. Like dangsanak, sometimes 
Banjarese people consider others as kula even though they are not related by blood. Kula underlines the fact that human beings are one big family so that no matter where Banjarese meets, especially outside their territory, they will consider one another as kula.

\section{CONCLUSIONS}

Wayang Gung is a traditional art that is not only entertaining but also worth conserving. The language used in Wayang Gung reflects the identities of the Banjarese people. Based on the investigation of Wayang Gung scripts, it is concluded that Banjarese people take religion, persistence, and togetherness as parts of their identities. Islamic teachings become parts of the daily life of Banjarese people, including their linguistic activities. Banjarese people also value loyalty and kinship in their lives that makes them hardly become individualists.

\section{REFERENCES}

Chaer, A. (1994). Semantik. Jakarta: Rineka Cipta.

Endraswara, S. (2015). Etnologi Jawa Penelitian, Perbandingan, dan Pemaknaan . Yogyakarta: CAPS (Center for Academic Publishing).

Foley, W. A. (2001). Anthropological Linguistics: An Introduction. Massachusetts : Blackwell Publishers.

Kemdikbud. (2017, January 1). Warisan Budaya Tak Benda. Retrieved from kemdikbud.go.id:

https://warisanbudaya.kemdikbud.go.id/?newdetail\&detailTetap=545

Mukhtar. (2013). Metode Penelitian Deskriptif Kualitatif. Jakarta: GP Press Group.

Natalika, D. (2014, December 4). budaya-indonesia.org. Retrieved from budaya indonesia: https://budaya-indonesia.org/Wayang-Gung

Sartini, N. W. (2009). Menggali Nilai Kearifan Lokal Budaya Jawa Lewat Ungkapan . Surabaya: Universitas Airlangga.

Sugiyono. (2008). Metode Penelitian Kuantitatif, Kualitatif, dan R\&D. Bandung: Alfa Beta. 
Wakit, A. (2014). Etnolinguistik: Teori, Metode, dan Aplikasinya. Surakarta: UNS Press. 